
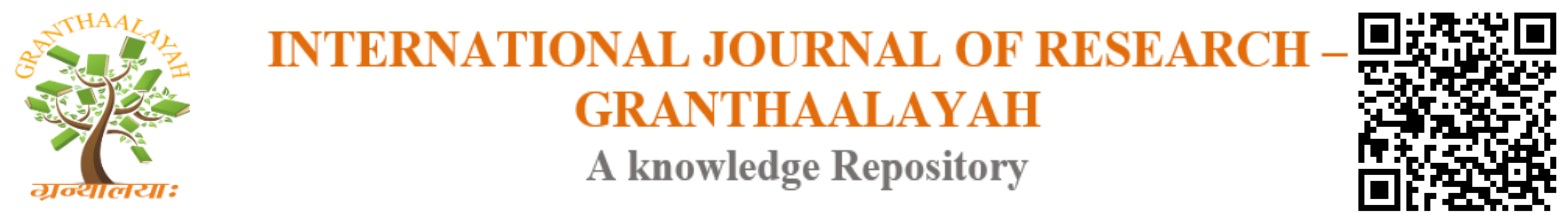

Management

\title{
EARNING MANAGEMENT MODELING BASED ON FINANCIAL COMMUNICATION
}

\author{
Mojtaba Mortezaee *1 \\ ${ }^{* 1}$ Accounting and Finance Department, Islamic Azad University of Mashhad, Iran
}

\begin{abstract}
The present research is focused on financial communication area and aim to investigate the relationship between company's web-based financial communications, information asymmetry and earning management. The research is aim to examine whether financial communication besides its usefulness could be act as contributory means for management in order to earning management. In other words, aim to challenges management incentives toward web-based financial information disclosure.
\end{abstract}

Keywords: Financial Communications; Signaling Theory; Asymmetry Information; Earning Management.

Cite This Article: Mojtaba Mortezaee. (2018). "EARNING MANAGEMENT MODELING BASED ON FINANCIAL COMMUNICATION." International Journal of Research Granthaalayah, 6(10), 274-279. https://doi.org/10.29121/granthaalayah.v6.i10.2018.1194.

\section{Introduction}

\subsection{Financial Communication}

Financial communication is consider as any activity for financial information and for promoting the financial image of the entity1 and provide the basis of institutional communication2. Signaling theory is the main theory which will be considered in present research. Signaling theory is useful for describing behavior when two parties (individuals or organizations) have access to different information3. Among the vectors of financial communication strategy, the internet must be underlined as the most important4-8. Besides signaling theory the cultivation analysis theory argues that media plays an extremely important role in how people view their world. According to Cultivation Analysis, in modern culture most people get much of their information in a mediated fashion. Spiral of Silence Theory argue that due to their enormous power, the internet communication as mass media9 have a lasting effect on public opinion. 


\subsection{Asymmetry Information}

Signaling theory is fundamentally concerned with reducing information asymmetry between two parties10. Inter-departmental knowledge asymmetries of this kind potentially pose problems for organizations in as much as they may give rise to misunderstandings, increased communication costs, hinder coordination efforts11. Traditional knowledge gap models 12 assume that one party in a communicative event has relevant and sufficient knowledge (the "have" position) whereas the other does not (the "have not" position), and that this gap tends to widen over time13.

\subsection{Earning Management}

Theorists in cultural studies maintain that the internet communication as a mass media represents ideologies of the dominant class in a society. Because media are controlled by corporations, the information presented to the public is necessarily influenced and framed with profit in mind. Cultural Studies theorists, therefore, are concerned with media influenced and framed with profit in mind. According to14, earnings management occurs when managers use judgment in financial reporting to alter financial reports15. Academics often use agency theory in describing earnings management behavior. More importantly, the essence of signaling theory is that the performer can purposively modify one or more of said variables for communicative purposes 16.

\section{Explain the Theoretical Connections}

This section try to explain the theatrical connections between variables which are based on communication theories and also is an introduction to problem statement. Relationship between Internet Financial communication, Asymmetry information and Earning Management can be explain through Signaling Theory, Cultivation Analysis Theory, Spiral of Silence Theory and Cultural studies. Thus, based on Cultivation analysis theory mass media (internet) plays an extremely important role in how people view their world. In the following; Spiral of Silence Theory argue that due to their enormous power, the internet communication as mass media17 have a lasting effect on public opinion and then considering internet financial communication under web, signaling theory is fundamentally concerned information asymmetry between two parties (management as agent of company and stakeholders) and finally Cultural Studies theorists, are concerned with mass media influenced and framed with profit in mind which could be as a motivating factor for earning management.

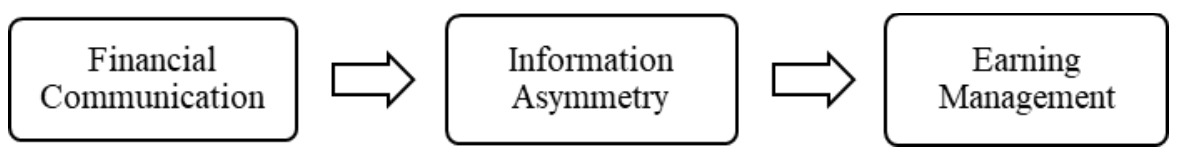

Figure 1: Conceptual Framework

\section{Modeling}

\subsection{Internet Financial Communication}

Evaluate the level of financial communication on company's websites is approached by a financial communication score by scoring technique and analysis grid of websites are practices use to evaluate information disclosure levels17-20. The earlier works propose below model (1) : 
Financial Communication Score $=\alpha+\beta 1$ (Market) $+\beta 2$ (Size) $+\beta 3$ (Sector) $+\beta 4$ (Capital

Structure $)+\beta 5$ (Level of Debts) $+\beta 6$ (Performance) $+\beta 7$ (Growth)

Where;

Market $=$ explanatory variables of financial disclosure on the internet

Size $=$ natural logarithm of the total assets

Sector $=$ considering statistical sample study assigned a value of 1 or 0

Capital Structure = subtracting shares held by leaders and institutional investors from the entirety of shares on the market

Level of debts $=$ ratio of long-term debts to the total assets

Performance $=$ can be measure in terms of ROA before amortization or ROE before tax

Growth $=$ the difference between the market value and the book value

\subsection{Financial Communication Based on Weighted Parameters}

It should be noted that unlike previous studies different weight $(\mathrm{Wi}, \mathrm{j})$ base on analysis gird of web sites 18 in four different area includes; financial reports, investor information, website's ergonomy and firm profile.

\subsection{Information Asymmetry}

In order to construct the information asymmetry (IA) index, denoted as IA_INDEX. The largest (smallest) value the variable IA_INDEX shows the highest (lowest) degree of information asymmetry 21 . Thus, Information asymmetry index model based on financial communication can be proposed as follows:

IA_INDEX $=\sum_{j=1}^{10} \beta_{j} \sum_{i=1}^{7} w_{i, j} \lambda_{i, j}$

and in expanded form;

IA_INDEX $=\beta \_0+\beta \_1\left(\mathrm{w} \_(1,1) \lambda \_1,1+\mathrm{w} \_(2,1) \lambda \_2,1+\ldots+\mathrm{w} \_(7,1) \lambda \_7,1\right)+\beta \_2\left(\mathrm{w} \_(1,2\right.$ $\left.\lambda \_1,2+\mathrm{w} \_(2,2) \lambda \_2, \overline{2}+\ldots+\mathrm{w} \_(7, \overline{2}) \lambda \_7,2\right)+\ldots+\bar{\beta} \_10\left(\mathrm{w} \_(1,10) \lambda \_1,10+\mathrm{w} \_(2, \overline{10}) \lambda \_-2,10\right.$ $\left.+\ldots+\mathrm{w}_{-}(\overline{7}, 10) \lambda \_\overline{7}, 10\right)$

Where;

IA_INDEX = Information asymmetry index based on internet financial communication $\beta \ldots \mathrm{j}=$ Information asymmetry variables coefficient

$\mathrm{w}_{-}(\mathrm{i}, \mathrm{j})=$ Weight of internet financial communication in Information asymmetry index

$\lambda_{-}(\mathrm{i}, \mathrm{j})=$ Regression model coefficients determined in the analysis

$$
w_{i, j}^{2}=\sigma_{y . i}^{2}+\sum_{i=j}^{n}\left(\frac{\partial f}{\partial x_{j, i}}\right)^{2} \sigma_{j . i}^{2}
$$

Where; $\mathrm{w}_{-}(\mathrm{i}, \mathrm{j})=$ Weight applied to the ith data point, $\sigma_{-}(\mathrm{y} . \mathrm{i})^{\wedge} 2=$ Variance of the ith y value $\mathrm{jth}, \sigma_{-}(\mathrm{j} . \mathrm{i})^{\wedge} 2$

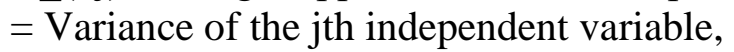
$\mathrm{xi}$ at the ith data point, $\mathrm{n}=$ number of dependent variables, $\mathrm{m}=$ number of data point. 


\section{Conclusion (Final Modeling)}

Present research use of discretionary accruals 22 in tests of earnings management model based on financial communication. Cross sectional within-industry discretionary accruals are the residuals from the Jones model. Discretionary accruals from the Jones model are estimated for each industry and year as follows:

$$
\mathrm{TACC}_{\mathrm{t}}=\alpha_{0}\left(\frac{1}{\text { Assets } \mathrm{t}-1}\right)+\alpha_{1} \Delta \text { sale }_{\mathrm{t}}+\alpha_{2} \mathrm{PPE}_{\mathrm{t}}+\alpha_{3} \mathrm{ROA}_{\mathrm{t}}+\varepsilon_{\mathrm{t}}
$$

With parameters obtained from the accruals regression, nondiscretionary accruals are estimated as:

$$
\mathrm{NDACC}_{\mathrm{t}}=\mathrm{a}_{0}\left(\frac{1}{\text { Assets t-1 }}\right)+\mathrm{a}_{1} \Delta \text { sale }_{\mathrm{t}}+\mathrm{a}_{2} \mathrm{PPE}_{\mathrm{t}}+\mathrm{a}_{3} \mathrm{ROA}_{\mathrm{t}}
$$

Where;

TACC $_{\mathrm{t}}=$ total accruals

NDACC $_{t}=$ nondiscretionary accruals

$\Delta$ sale $^{t}=$ equals the change in the firm's sales from year $\mathrm{t}-1$ to year $\mathrm{t}$

$\mathrm{PPE}_{\mathrm{t}}=$ equals the firm's gross property, plant, and equipment at year $\mathrm{t}$

$\mathrm{ROA}_{\mathrm{t}}=$ return on asset (net income over total assets) at year $\mathrm{t}$

â1, â2, â3 = estimated parameter for firm i

$\alpha 1, \alpha 2, \alpha 3=$ estimated and denoted as â1, â2, â3 respectively

$\varepsilon \mathrm{t}=$ discretionary accruals for firm $\mathrm{i}$, in year $\mathrm{t}$

The parameters in above equation can be estimated using either time-series data of each firm 23 or cross-sectional data24. To calculate the matched Jones model discretionary accrual for firm i we subtract the Jones-model discretionary accrual of the firm with the closest return on assets (ROA) that is in the same industry as firm i. Matching is based on ROA in year t-1, which is earning management index.

\section{$\mathrm{DACC}=\mathrm{TACC}-\mathrm{NDACC}$}

To test proposed questions, use multivariate analysis. Finally, use following multiple regression consist of five information asymmetry measure in order to measure earning management.

$\mid$ DACC $_{i, t} \mid=\alpha_{0}+\alpha_{1}$ IA_INDEX $_{i, t}+\alpha_{2}$ DEBT $_{i, t}+\alpha_{3}$ MKTBV $_{i, t}+\alpha_{4}$ SIZE $_{i, t}+\alpha_{5}$ GROWTH $_{i, t}+$ $\varepsilon_{\text {it }}$

Where;

DACC $=$ is the discretionary (managed) accounting accruals under modified Jones model

IA_INDEX $i, t=$ information asymmetry index which is calculate based on financial communication

$\operatorname{DEBT}_{i, t}=$ ratio of long-term debt divided by the book value of equity

MKTBV $_{i, t}=$ market capitalization divided by the book value of equity

$\mathrm{SIZE}_{i, t}=$ natural $\log$ of the market capitalization 
GROWTH $_{\mathrm{i}, \mathrm{t}}=$ net revenues (current year) less net revenues (previous year) scaled by net revenues for the previous year.

The test of the model will be performed by estimating $\alpha 1$. It is anticipated that a $\alpha 1$ that is significantly greater that zero would provide evidence of a positive effect of information asymmetry level based on financial communication on the magnitude of earning management.

\section{References}

[1] Léger, J. Y. (2010). La communication financière. Dunod.

[2] Avram, M., \& Avram, V. (2014). "Considerations Regarding The Accounting Principles Applied In Insolvency Proceedings". Annals of University of Craiova-Economic Sciences Series, 1 (42), 172-177.

[3] Connelly, S. Trevis Certo, R. Duane Ireland, Christopher R. Reutzel. (2011). "Signaling Theory: A review and assessment". Journal of Management. pp. 39-67.

[4] Guillamón-Saorín, E., \& Martínez-López, F. J. (2013). Corporate financial communication and the internet: manipulating investor audiences? Online information review, 37(4), 518537.

[5] Sandu, R. (2009). Comunicarea financiară prin intermediul internetului în ţările în tranziţiemodele şi provocări-Vasile ROBU. Analiza economico-financiară şi evaluarea proprietăţilor, 66.

[6] Leger, J.Y., (2008). La communication Financière, Paris, DUNOD, 2ème edition, 278.

[7] Barredy C., Darras N. (2008). "L'utilisation d'Internet dans la communication auprès des actionnaires minoritaires dans les entreprises familiales cotées », Journal des entreprises familiales, volume 1, n1, Hiver.41-68.

[8] Almillia L., Budisusetyo S. (2008). "Corporate Internet reporting of banking industry and LQ45 firms: an Indonesian example", Proceeding of the first Parahyangan international Accounting and Business conference, Bandung, February 13-15, p. 1-26.

[9] Morris, M., \& Ogan, C. (1996). "The Internet as mass medium". Journal of Communications, 46(1), $39-50$.

[10] Spence, M. 2002. Signaling in retrospect and the informational structure of markets. American Economic Review, 92: 434-459.

[11] Kastberg, P. (2011). "Knowledge Asymmetries - Beyond 'To Have and Have Not'." Fachsprache - International Journal of Specialized Communication [3-4]: 137-151.

[12] Thunberg, Anne Marie et al: (1982): Communication and Equality: A Swedish Perspective. Stockholm: Almquist \& Wicksell.

[13] Bensaude-Vincent, Bernadette. (2001). "A genealogy of the increasing gap between science and the public" Public Understanding of Science 10: 99-113.

[14] Healy, P., \& Wahlen, J. (1999). A review of the earnings management literature and its implications for standard setting. Accounting Horizons, 13(4), 365-383.

[15] Richardson, V. (2000). Information asymmetry and earnings management: some evidence. Review of Quantitative Finance and Accounting, 15(4), 325-347.

[16] Pezzulo G, Candidi M, Dindo H, Barca L. (2013). Action simulation in the human brain: Twelve questions. New Ideas in Psychology.

[17] Larran, M. \& Giner, B. (2001) "The use of internet for corporate reporting by Spanish companies", The International Journal of Digital Accounting, vol. 2, no. 1, p. 53-82.

[18] Pozniak L. (2010), "Financial Communication on the Web - Evidence from Belgium", Accounting \& Taxation, volume $2, \mathrm{n}^{\circ} 1, \mathrm{p} .47-58$.

[19] Pozniak L. \& Croquet M. (2011) “Analyse des déterminants de la communication financière sur le net. Le cas des Marchés non réglementés de la Bourse de Bruxelles," Journal of Small Business and Entrepreneurship, vol. 24, no. 3, p. 329-344. 
[20] Pozniak, L. (2013). The Relationship between Financial Communication and Firm Performance: Evidence from France.

[21] Peyer, U. and T. Vermaelen. (2009): “The Nature and Persistence of Buyback Anomalies," Review of Financial Studies, 22, 1693-1745.

[22] Kothari, S. P., A. Leone, and C. Wasley. (2005). Performance matched discretionary accrual measures. Journal of Accounting and Economics 39 (1): 163-197.

[23] Jones, J. (1991). Earnings management during import relief investigation. Journal of Accounting 29, 193-228.

[24] Xie, H. (2001). The mispricing of abnormal accruals. The Accounting Review 76, 357-373.

*Corresponding author.

E-mail address: mojtaba.mortezaee1984@ gmail.com 